\title{
Haemodynamic changes in emergency department patients with poorly controlled hypertension
}

\author{
Stewart SW Chan *, Mandy M Tse, Cangel PY Chan, Marcus CK Tai, Colin A Graham, Timothy H Rainer
}

This article was published on 29 Jan 2016 at www.hkmj.org.

\section{A B S T R A C T}

Objectives: This study aimed to measure cardiac output, systemic vascular resistance, cardiac index, and systemic vascular resistance index in emergency department patients with poorly controlled hypertension; and to determine the frequency in which antihypertensive drugs prescribed do not address the predominant haemodynamic abnormality.

Methods: This cross-sectional observational study was conducted in an emergency department of a 1400-bed tertiary hospital in Hong Kong. Patients aged 18 years or above, with systolic blood pressure of $\geq 160 \mathrm{~mm} \mathrm{Hg}$ or diastolic blood pressure of $\geq 100$ $\mathrm{mm} \mathrm{Hg}$ based on two or more measurements and on two separate occasions within 2 to 14 days, were included. Haemodynamic measurements were obtained using a non-invasive Doppler ultrasound monitor. Doctors were blinded to the haemodynamic data. Any antihypertensive medication adjustment was evaluated for correlation with haemodynamic changes.

Results: Overall, 164 patients were included. Their mean age was 69.0 years and 97 (59.1\%) were females. Systemic vascular resistance and cardiac output were elevated in $65.8 \%$ (95\% confidence interval, $57.9-72.9 \%)$ and $15.8 \%(10.8-22.5 \%)$ of patients, respectively. Systemic vascular resistance index and cardiac index were elevated in 43.9\% (95\% confidence interval, 36.2-51.8\%) and 19.5\% (13.9$26.5 \%)$ of patients, respectively. Of 71 patients in whom antihypertensive medications were adjusted, 25 (35.2\%; 95\% confidence interval, 24.5-47.5\%) were prescribed agents that did not correlate with the primary haemodynamic abnormality.

Conclusions: The profile of haemodynamic changes in emergency department patients with poorly controlled hypertension is characterised. The antihypertensive drugs prescribed did not correspond to the patient's primary haemodynamic derangement in $35 \%$ of cases.

\section{Hong Kong Med J 2016;22:116-23}

DOI: $10.12809 / \mathrm{hkmj} 154566$

SSW Chan *, MSc, FHKAM (Emergency Medicine)

MM Tse, BSc, MPhil

CPY Chan, PhD

MCK Tai, MB ChB, FHKAM (Emergency Medicine)

CA Graham, FRCPEd, FHKAM (Emergency Medicine)

TH Rainer, FHKAM (Emergency Medicine), FIFEM

Accident and Emergency Medicine Academic Unit, Prince of Wales Hospital, The Chinese University of Hong Kong, Shatin, Hong Kong

* Corresponding author: stewart_chan@hotmail.com

New knowledge added by this study

- This is the first study to delineate the haemodynamic characteristics of Hong Kong emergency department (ED) patients with poorly controlled hypertension.

- Antihypertensive drugs prescribed in the ED did not correlate with the patient's primary haemodynamic derangement in $35 \%$ of cases.

Implications for clinical practice or policy

A haemodynamically guided approach to drug therapy should be further investigated as it may lower blood pressure more effectively in a large proportion of patients.

\section{Introduction}

Hypertension is an important risk factor for cardiovascular disease, cardiovascular events, and death. It was estimated that in the year 2000, 972 million adults in the world had hypertension, and that by 2025 , this number will increase by $60 \%$. Within the US, from 2009 to $2010,29.5 \%$ of adults were affected by hypertension, of whom only $45.1 \%$ had blood pressure (BP) under control, which is below 140/90 $\mathrm{mm} \mathrm{Hg.}{ }^{2}$ Uncontrolled hypertension is present in about $69 \%, 77 \%$, and $74 \%$ of patients with a first myocardial infarction, patients with a first stroke, and patients with congestive heart failure, respectively. ${ }^{3}$ Blood pressure control is an important factor in preventing or delaying the development of end-stage renal disease and congestive heart failure and also relieves symptoms associated with congestive heart failure. ${ }^{4,5}$ Control of hypertension is 
also essential in stroke prevention. ${ }^{6}$

Hypertension is associated with increased cardiac output (CO) and/or increased systemic vascular resistance (SVR), according to the relationship: $\mathrm{BP}=\mathrm{CO} \times \mathrm{SVR} .^{7}$ Clarification of the associated haemodynamic pathophysiology of hypertensive patients may allow a more tailored choice of antihypertensive drugs, resulting in more effective BP control. Patients with elevated CO may benefit more from primary treatment with agents that lower CO, while patients with elevated SVR may benefit more from primary treatment with agents that reduce SVR. This haemodynamically guided approach is feasible in the clinical setting, provided there is a simple and accurate method of measuring $\mathrm{CO}$ and SVR. These parameters are readily obtained non-invasively at the point-of-care by the Ultrasonic Cardiac Output Monitor (USCOM; USCOM Ltd, Sydney, Australia) that uses continuous-wave Doppler ultrasound transcutaneously to detect the velocity of blood flowing through the aortic valve or pulmonary valve. ${ }^{8,9}$ The time to read out is less than 3 minutes.

In current practice, doctors who encounter patients with poorly controlled hypertension are often unable to choose an antihypertensive agent with respect to the pattern of haemodynamic derangement. This is particularly relevant in the emergency department (ED) because, according to a report from the US Centers for Disease Control and Prevention and National Center for Health Statistics, BP is severely elevated (with systolic BP of $\geq 160 \mathrm{~mm} \mathrm{Hg}$ or diastolic BP of $\geq 100 \mathrm{~mm} \mathrm{Hg}$ ) in $16.3 \%$ of ED visits. ${ }^{10}$ We therefore aimed to investigate the haemodynamic changes in this group of ED patients with severely elevated, poorly controlled hypertension, and to determine whether antihypertensive drugs prescribed to them correlate with these changes.

This study aimed to measure the CO, SVR, cardiac index (CI), and SVR index (SVRI) in ED patients with poorly controlled hypertension. It also aimed to determine the frequency with which antihypertensive medications prescribed in the ED setting did not correspond to the predominant haemodynamic abnormality for such patients.

\section{Methods}

Our setting was an academic ED of a 1400-bed tertiary hospital in Hong Kong, with an annual ED attendance of over 150000 cases. Patients aged 18 years or above, with systolic BP of $\geq 160 \mathrm{~mm} \mathrm{Hg}$ or diastolic BP of $\geq 100 \mathrm{~mm} \mathrm{Hg}$ based on two or more BP measurements at least 20 minutes apart and on two separate occasions within 2 to 14 days, were included in the study. Patients were excluded if they were pregnant or lactating, and if they presented with a hypertensive emergency such as stroke.

\section{高血壓控制不良的急症患者的血流動力學變化} 陳兆華、謝雯、陳佩兒、戴俊權、簡家簾、譚偉恩

目的：本研究旨在量度高血壓控制不良的急症患者的心輸出量、全身 血管阻力、心藏指數和全身血管阻力指數, 以及處方給患者的降壓藥 物中沒有針對主要血液動力學異常的比率。

方法：這項橫斷面觀察研究於香港一所提供 1400個床位的第三層醫 療服務的醫院急症科內進行。被納入研究範圍的患者均為 18 歲或以 上, 並且在 2 至 14 天內兩個不同場合中量度到兩次或以上的收縮壓 $\geq 160 \mathrm{~mm} \mathrm{Hg}$ 或舒張壓 $\geq 100 \mathrm{~mm} \mathrm{Hg}$ 。使用非侵入性超聲多普勒量度患 者的血流動力學。參與研究的醫生不知道患者的血流動力學數據, 然 後評估所有曾經被調整的降壓藥物與血流動力學變化的相關性

結果：共164名患者被納入研究, 其中97人（59.1\%）為女性。患者 平均年齡 69.0歲。患者中有 $65.8 \%$ （95\%置信區間： $57.9-72.9 \%)$ 的 全身血管阻力上升, 另 $15.8 \%$ (10.8-22.5\%) 的心輸出量上升。 $43.9 \%$ ( $95 \%$ 置信區間：36.2-51.8\%) 的全身血管阻力指數上升, 另有 $19.5 \%$ (13.9-26.5\%) 的心臟指數上升。71名患者的降壓藥物進行了 調整，當中 25 人 $(35.2 \% ； 95 \%$ 置信區間：24.5-47.5\%) 所處方的藥 物與主要血液動力學異常並無相關。

結論：對於高血壓控制不良的急症患者, 本研究已掌握了其血流動力 學變化的特點，而35\%患者所處方的降壓藥物並沒有針對主要血液動 力學紊亂的原因。

Patients' haemodynamic profile was obtained by using USCOM. A transducer was placed transcutaneously in either the left parasternal position to measure blood flow through the pulmonary valve, or the suprasternal position to measure blood flow through the aortic valve. The approach giving a tracing that better fulfilled the optimal Doppler flow profile characteristics was chosen. Measures of CO, CI, SVR, and SVRI were obtained by trained operators as shown in Figure 1, with patients examined supine and after 5 minutes' resting. Stroke volume (SV) and heart rate (HR) were measured by USCOM, with CO calculated as the product of SV and HR; SVR was then obtained according to the relationship: $S V R=$ mean arterial pressure/CO. The SVRI and CI are SVR and CO respectively normalised for body surface area.

For the purpose of recruiting patients, BP was measured with an appropriately sized cuff using a standard oscillometric device with the patient in a sitting position, unless precluded by physical condition, according to the US National Heart, Lung, and Blood Institute recommendation. ${ }^{11}$ After prospective patients had been recruited, for the purpose of haemodynamic calculations, the supine position was used for BP measurement just before the acquisition of haemodynamic data, according to standard operating instructions and specifications of the machine. This supine BP reading was manually 


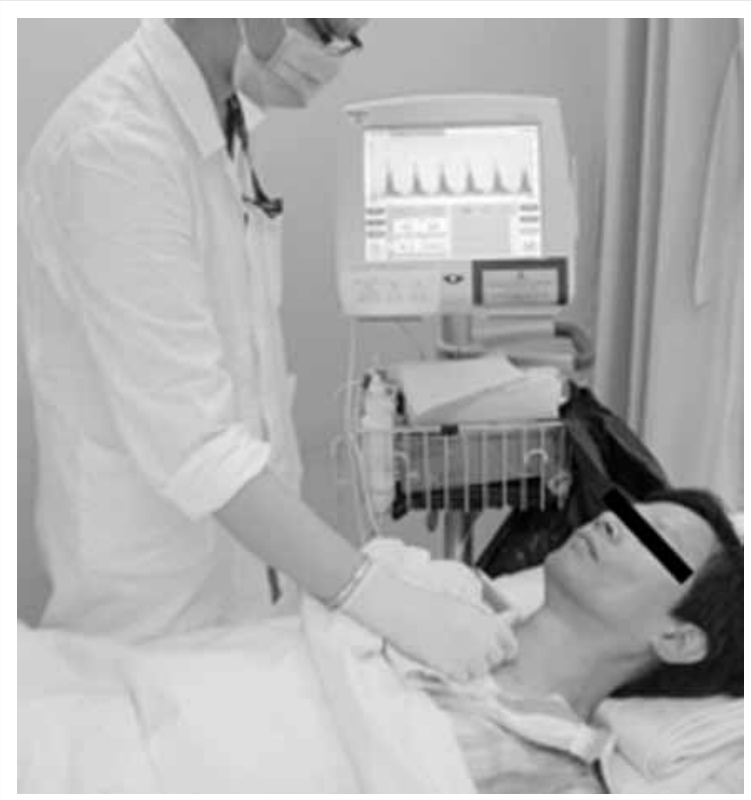

FIG I. Collection of haemodynamic data in the emergency department using the Ultrasonic Cardiac Output Monitor entered into the USCOM device for subsequent computations. Demographic, anthropometric, and clinical data such as co-morbidity and current medications were also collected and entered into a database. The ED physicians were blinded to the haemodynamic profile of patients and all antihypertensive medication changes were documented. These ED doctors did not follow any particular set of practice guidelines or study protocol when they made medication changes, but managed each individual case according to their own clinical judgement, as they would in their everyday practice. All patients were recruited from 9:00 am to 5:00 pm, Monday to Friday, over a consecutive 9-month period. They were followed up as clinically indicated within 2 to 14 days. This was essentially a single-centre cross-sectional study as far as the first objective was concerned. The prospective observational follow-up assessments ensured that patients with elevated BP who fulfilled the inclusion criteria at the first visit, but whose elevated BP was not sustained at the followup visit, could be excluded from the study. Approval from the Clinical Research Ethics Committee of the authors' institution was obtained prior to study commencement. All patients gave written consent to participate with full knowledge of the nature of this research.

\section{Statistical analyses}

The primary outcome measure was the $\mathrm{CO}$ estimated by USCOM. Although our literature search failed to identify any USCOM-derived range for $\mathrm{CO}$ values in hypertensive patients, the reference range for healthy subjects aged 16 to 60 years is reported to be 3.5 to $8.0 \mathrm{~L} / \mathrm{min}$. Assuming that this follows a normal distribution, with the upper and lower values defining the $95 \%$ confidence interval, the standard deviation (SD) was calculated to be 1.13. The total width of the confidence interval desired was $0.4 \mathrm{~L} / \mathrm{min}$. For a confidence level of $95 \%$, the required sample size was thus estimated to be $126 .{ }^{12}$ Continuous variables were analysed using unpaired 2 -tailed $t$ test or paired $t$ test where appropriate, and categorical data were analysed using the Chi squared test or Fisher's exact test. Stepwise logistic regression analysis was used to identify independent predictors of patients with elevated CO, CI, SVR, and SVRI. Variables were entered into the model if $\mathrm{P}<0.05$. All data were analysed using the Statistical Package for the Social Sciences (Windows version 18.0; SPSS Inc, Chicago [IL], US), and MedCalc version 11.5.1 (MedCalc Software; Mariakerke, Belgium).

\section{Evaluation of the correlation between haemodynamic profile and antihypertensive drug}

The second part of the study was a retrospective review of prospectively collected data. We investigated five different classes of antihypertensive drugs: angiotensin-converting enzyme (ACE) inhibitors, angiotensin II receptor blockers (ARBs), calcium channel blockers (CCBs), beta blockers, and diuretics. Each patient's antihypertensive medication was assessed against a theoretical model of guidance based on measured haemodynamic abnormality of the patient. The protocol is illustrated in Table 1, and shows the types of haemodynamic change, the corresponding optimal antihypertensive drug selection, and the criteria by which the actual drug selected would not correspond to the primary haemodynamic characteristics. For each case in which antihypertensive drugs were identified as not correlating with the primary haemodynamic abnormality, the case notes were reviewed to ensure that the choice of medication was not influenced or limited by known drug allergies or a history of adverse drug reactions to the more appropriate drug class.

\section{Results}

Of 232 patients who were assessed for the study, 68 patients were excluded (9 defaulted follow-up, 54 with $\mathrm{BP}<160 / 100 \mathrm{~mm} \mathrm{Hg}$ at follow-up, and 5 with unsuccessful USCOM measurements), leaving a total of 164 patients. The mean age was 69.0 (SD, 14.7) years, with a median of 72 years and interquartile range of 21.3 years. Of the patients, 97 (59.1\%) were females. The mean body mass index (BMI) was 25.3 $\mathrm{kg} / \mathrm{m}^{2}$ (SD, 4.3; range, $16.1-42.3 \mathrm{~kg} / \mathrm{m}^{2}$ ). The mean 
TABLE I. Types of haemodynamic changes and the criteria by which drug adjustment from the emergency department would not correspond to the primary haemodynamic characteristics

\begin{tabular}{ll}
\hline Haemodynamic changes & Antihypertensive drug adjustment that would not correlate with haemodynamic changes \\
\hline Elevated SVR or SVRI & Antihypertensives other than ACE inhibitors, ARB or CCB were used \\
Reduced SVR or SVRI & Antihypertensives used included ACE inhibitors, ARB, or CCB \\
Elevated CO or Cl & Antihypertensives other than beta blockers or diuretics were used \\
Reduced CO or Cl & Antihypertensives used included beta blockers or diuretics \\
\hline
\end{tabular}

Abbreviations: $\mathrm{ACE}=$ angiotensin-converting enzyme; $\mathrm{ARB}=$ angiotensin $\mathrm{II}$ receptor blockers; $\mathrm{CCB}=$ calcium channel blockers; $\mathrm{Cl}=$ cardiac index; $\mathrm{CO}=$ cardiac output; SVR = systemic vascular resistance; $\mathrm{SVRI}=$ systemic vascular resistance index

body weight was $67.7 \mathrm{~kg}$ (SD, 10.8; range, 42.6-92.9 $\mathrm{kg}$ ) for males, and $57.5 \mathrm{~kg}(\mathrm{SD}, 11.8$; range, 34.4$116.2 \mathrm{~kg}$ ) for females. The mean height was $164.1 \mathrm{~cm}$ (SD, 7.2; range, $149-186 \mathrm{~cm}$ ) for males, and $150.2 \mathrm{~cm}$ $(\mathrm{SD}, 6.7$; range, $136.2-172.3 \mathrm{~cm}$ ) for females. Systolic and diastolic BP values together with HR from two separate visits are shown in Figure 2. Of the 164 patients included, with regard to confounding factors that might increase BP, 67 (40.9\%) had complained of pain, $13(7.9 \%)$ had an injury, two (1.2\%) had symptoms of anxiety, 14 (8.5\%) had an infection, and seven (4.3\%) presented with fever. For the 14 cases with infection, the sources of infection were soft tissue $(n=5)$, gastrointestinal tract $(n=4)$, upper respiratory tract $(n=3)$, lower respiratory tract $(n=1)$, and urinary tract $(\mathrm{n}=1)$. With regard to co-morbidity, $40(24.4 \%)$ patients also had diabetes, 53 (32.3\%) had hyperlipidaemia, 19 (11.6\%) had heart disease, and $20(12.2 \%)$ had a history of stroke. Of the patients, 46 (28.0\%) were never diagnosed to have hypertension. In addition, 20 (12.2\%) patients were smokers and 26 (15.9\%) were obese $\left(\right.$ BMI $\left.>30 \mathrm{~kg} / \mathrm{m}^{2}\right)$.

The SVR was elevated above reference range in $65.8 \%$ (95\% confidence interval, 57.9-72.9\%) of patients, while $\mathrm{CO}$ was elevated above reference range in $15.8 \%(10.8-22.5 \%)$ of patients. Similarly, SVRI was elevated above reference range in $43.9 \%$ (95\% confidence interval, 36.2-51.8\%) of patients, while CI was elevated above reference range in $19.5 \%$ (13.9-26.5\%) of patients. Only one patient had both SVR and CO elevated, while none of the patients had both SVRI and CI elevated.

Table $2^{13}$ shows the haemodynamic values (mean \pm SD) of study patients grouped according to associated pathophysiology.

Patients with elevated CI $(n=32)$ compared with those with normal or low CI $(n=132)$ were more likely to be female $(87.5 \%$ vs $52.3 \%$; $\mathrm{P}<0.001)$, older (mean age \pm SD, $75.3 \pm 11.7$ years vs $67.4 \pm$ 15.0 years; $\mathrm{P}=0.002)$, have lower body weight $(52.8$ $\pm 7.7 \mathrm{~kg}$ vs $63.8 \pm 12.4 \mathrm{~kg} ; \mathrm{P}<0.001)$, shorter stature $(152.3 \pm 8.4 \mathrm{~cm}$ vs $156.7 \pm 9.8 \mathrm{~cm} ; \mathrm{P}=0.021)$, and have significantly lower BMI $\left(22.8 \pm 3.1 \mathrm{~kg} / \mathrm{m}^{2}\right.$ vs $26.0 \pm$ $4.3 \mathrm{~kg} / \mathrm{m}^{2} ; \mathrm{P}<0.001$ ) [Table $3 \mathrm{a}$ ].

Patients with elevated SVRI $(n=72)$ compared

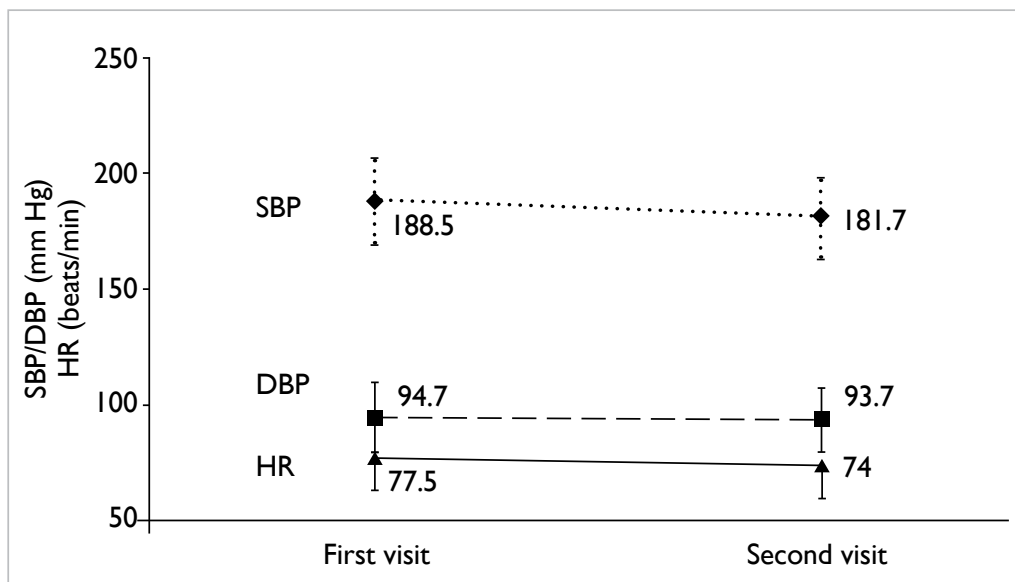

FIG 2. Systolic blood pressure (SBP), diastolic blood pressure (DBP), and heart rate (HR) of 164 patients at two separate visits

Error bars denote standard deviations; $\mathrm{P}$ values (difference between two visits, paired $t$ test) for SBP, DBP, and HR were $<0.001,0.232$, and 0.0013 , respectively

with those with normal or low SVRI $(n=92)$ were more likely to be male ( $51.4 \%$ vs $32.6 \%$; $\mathrm{P}=0.015)$, younger (mean age $\pm \mathrm{SD}, 64.9 \pm 13.5$ years vs $72.1 \pm$ 14.9 years; $\mathrm{P}=0.002)$, have higher body weight $(65.7 \pm$ $11.8 \mathrm{~kg}$ vs $58.6 \pm 12.0 \mathrm{~kg} ; \mathrm{P}<0.001)$, and significantly higher BMI $\left(26.5 \pm 4.4 \mathrm{~kg} / \mathrm{m}^{2}\right.$ vs $24.4 \pm 3.9 \mathrm{~kg} / \mathrm{m}^{2}$; $\mathrm{P}=0.001$ ) [Table $3 \mathrm{~b}$ ].

Using stepwise logistic regression analysis, independent predictors of elevated CI were: age $>70$ years (odds ratio $[\mathrm{OR}]=2.80 ; 95 \%$ confidence interval, $1.11-7.05)$ and female gender $(5.64 ; 1.81-17.5)$ after the model was adjusted for current smoker, diabetes, heart disease, hypertension, and stroke. Age above 70 years was an independent negative predictor of elevated SVRI with an OR of 0.32 (95\% confidence interval, 0.16-0.61) after the model was adjusted for sex, current smoker, diabetes, heart disease, hypertension, and stroke.

Doctors in ED initiated or added antihypertensive medications in 71 (43.3\%) of the 164 cases. These were given as a new prescription in 20 cases, as adjustment of usual medication regimen in 48 cases, and as resumption of omitted treatment 
TABLE 2. Haemodynamic values (mean \pm standard deviation) among study patients aged 18 to 60 years and $>60$ years with elevated SVR, elevated CO, both SVR and CO elevated, and both SVR and CO remained normal ${ }^{13}$

\begin{tabular}{|c|c|c|c|c|c|}
\hline $\begin{array}{l}\text { Haemodynamic value of } \\
\text { different age-groups }\end{array}$ & Elevated SVR & Elevated CO & $\begin{array}{l}\text { Both SVR and } \\
\text { CO elevated }\end{array}$ & $\begin{array}{l}\text { Both SVR and } \\
\text { CO normal }\end{array}$ & $\begin{array}{c}\text { Reference } \\
\text { range }^{13}\end{array}$ \\
\hline Age $18-60$ years & $(n=32)$ & $(n=4)$ & $(n=0)$ & $(n=7)$ & \\
\hline $\mathrm{CO}(\mathrm{L} / \mathrm{min})$ & $4.7 \pm 1.0$ & $8.8 \pm 0.5$ & - & $7.1 \pm 0.7$ & $3.5-8.0$ \\
\hline $\operatorname{SVR}\left(\right.$ d.s.cm $\left.{ }^{-5}\right)$ & $2463 \pm 744$ & $1131 \pm 145$ & - & $1416 \pm 132$ & $800-1600$ \\
\hline $\mathrm{Cl}\left(\mathrm{L} / \mathrm{min} / \mathrm{m}^{2}\right)$ & $2.7 \pm 0.7$ & $5.0 \pm 0.7$ & - & $3.7 \pm 0.4$ & $2.8-4.2$ \\
\hline SVRI (d.s.cm $\left.{ }^{-5} \mathrm{~m}^{2}\right)$ & $4430 \pm 1539$ & $2069 \pm 520$ & - & $2723 \pm 283$ & $1800-3200$ \\
\hline $\mathrm{HR}(\mathrm{bpm})$ & $82 \pm 15$ & $88 \pm 17$ & - & $84 \pm 9$ & - \\
\hline Age $>60$ years & $(n=75)$ & $(n=21)$ & $(n=1)$ & $(n=24)$ & \\
\hline $\mathrm{CO}(\mathrm{L} / \mathrm{min})$ & $4.3 \pm 0.8$ & $7.0 \pm 1.0$ & 6.5 & $5.5 \pm 0.3$ & $2.5-6.0$ \\
\hline SVR (d.s.cm-5) & $2429 \pm 616$ & $1414 \pm 187$ & 2066 & $1625 \pm 138$ & $1000-1800$ \\
\hline $\mathrm{Cl}\left(\mathrm{L} / \mathrm{min} / \mathrm{m}^{2}\right)$ & $2.7 \pm 0.6$ & $4.2 \pm 0.9$ & 4.1 & $3.6 \pm 0.5$ & $2.4-3.6$ \\
\hline SVRI (d.s.cm $\left.{ }^{-5} \mathrm{~m}^{2}\right)$ & $3897 \pm 1108$ & $2379 \pm 462$ & 3331 & $2485 \pm 370$ & $2000-3400$ \\
\hline $\mathrm{HR}(\mathrm{bpm})$ & $76 \pm 13$ & $81 \pm 15$ & 76 & $72 \pm 14$ & - \\
\hline
\end{tabular}

Abbreviations: bpm = beats per minute; $\mathrm{Cl}=$ cardiac index; $\mathrm{CO}=$ cardiac output; $\mathrm{HR}=$ heart rate; $\mathrm{SVR}=$ systemic vascular resistance; $\mathrm{SVRI}=$ systemic vascular resistance index

in three cases. The added drugs were given as monotherapy in 22 cases, and as combination therapy in 31 cases. In 22 cases, the dosage of existing drugs was increased. The drugs were all prescribed until follow-up.

Of these 71 cases, 25 (35.2\%; 95\% confidence interval, $24.5-47.5 \%$ ) were prescribed agents that did not correspond to the primary haemodynamic derangement. Chart review for each of these cases showed that the choice of medication was not influenced or limited by known drug allergies or a history of adverse drug reactions to the appropriate drug class. Table 4 shows how the choice of medication did not correlate with haemodynamic abnormalities in these 25 patients. The most frequent cause or scenario occurred in patients with elevated SVR or SVRI who were given antihypertensive drugs other than ACE inhibitors, ARBs, or CCBs. There were 11 such cases, representing 15.5\% (95\% confidence interval, $8.9 \%-25.7 \%$ ) of the 71 cases in which medications were adjusted.

\section{Discussion}

Blood pressure control is an important and costeffective means of reducing cardiovascular events, with their associated work absenteeism, loss of productivity, and hospitalisations.-6,14 According to the relationship that $\mathrm{BP}=\mathrm{CO} \times \mathrm{SVR}$, the pharmacotherapy of hypertension may be much improved by delineating and targeting the associated primary haemodynamic derangements that can be a relative elevation of $\mathrm{CO}$ or SVR or both. Just as the latest US and UK national guidelines for the management of hypertension have both recommended selection of antihypertensive agent based on associated factors such as age, ethnicity (black population) and co-morbid illnesses (chronic kidney disease and heart failure), selection based on haemodynamic pattern may also be considered in order to optimise BP control. ${ }^{15,16}$ It has been shown that guiding antihypertensive therapy using haemodynamic parameters measured by impedance cardiography results in improved BP control in the primary care setting. ${ }^{17,18}$ This same approach also improved BP control for patients with resistant hypertension in a hypertension specialty clinic. ${ }^{19}$ Although these studies were promising, their results might not be extrapolated to the ED setting. To the best of our knowledge, our study is the first in indexed literature to delineate the pathophysiologic haemodynamic patterns of hypertensive patients in the ED setting upon which future research can be based.

In our study, there were approximately 4 times as many patients with elevated SVR as elevated $\mathrm{CO}$, and slightly more than twice as many patients with elevated SVRI than with elevated CI. Approximately one third of patients with deranged haemodynamic parameters (32/104) have elevated CI. Thus, the proportion of patients with elevated $\mathrm{CO}$ or $\mathrm{CI}$, although less than patients with elevated SVR or SVRI, is still considerable. For these patients, antihypertensive therapy that aims to reduce $\mathrm{CO}$ may in theory be more effective than other agents. Diuretics and beta blockers, which primarily act to reduce $\mathrm{CO}$, may therefore still play important roles. Nevertheless the current UK guidelines have not included diuretics and beta blockers as firstline drugs; while the current US guidelines have not 
TABLE 3. Comparison of demographic features and co-morbidity (a) between patients with elevated $\mathrm{Cl}$ against those with normal or low $\mathrm{Cl}$, and between patients with elevated CO against those with normal or low CO; and (b) between patients with elevated SVRI against those with normal or low SVRI, and between patients with elevated SVR against those with normal or low SVR

(a)

\begin{tabular}{|c|c|c|c|c|c|c|}
\hline & $\begin{array}{c}\text { Elevated Cl } \\
\quad(n=32)\end{array}$ & $\begin{array}{l}\text { Normal or low } \\
\quad \mathrm{Cl}(\mathrm{n}=132)\end{array}$ & $P$ value & $\begin{array}{l}\text { Elevated CO } \\
\quad(n=26)\end{array}$ & $\begin{array}{l}\text { Normal or low } \\
\text { CO }(n=138)\end{array}$ & $P$ value \\
\hline Gender & & & $<0.001$ & & & 0.787 \\
\hline Male & $4(12.5 \%)$ & $63(47.7 \%)$ & & $10(38.5 \%)$ & $57(41.3 \%)$ & \\
\hline Female & $28(87.5 \%)$ & $69(52.3 \%)$ & & $16(61.5 \%)$ & $81(58.7 \%)$ & \\
\hline Age (years) & $75.3 \pm 11.7$ & $67.4 \pm 15.0$ & 0.002 & $73.5 \pm 12.7$ & $68.1 \pm 14.9$ & 0.087 \\
\hline Weight (kg) & $52.8 \pm 7.7$ & $63.8 \pm 12.4$ & $<0.001$ & $63.3 \pm 12.0$ & $61.4 \pm 12.5$ & 0.473 \\
\hline Height (cm) & $152.3 \pm 8.4$ & $156.7 \pm 9.8$ & 0.021 & $158.3 \pm 11.1$ & $155.4 \pm 9.4$ & 0.165 \\
\hline BMI $\left(\mathrm{kg} / \mathrm{m}^{2}\right)$ & $22.8 \pm 3.1$ & $26.0 \pm 4.3$ & $<0.001$ & $25.3 \pm 4.3$ & $25.3 \pm 4.3$ & 0.960 \\
\hline Diabetes & $10(31.3 \%)$ & $30(22.7 \%)$ & 0.021 & $12(46.2 \%)$ & $28(20.3 \%)$ & 0.005 \\
\hline Hyperlipidaemia & 15 (46.9\%) & $38(28.8 \%)$ & 0.05 & $13(50.0 \%)$ & $40(29.0 \%)$ & 0.036 \\
\hline $\begin{array}{l}\text { Heart disease (congestive heart failure or } \\
\text { coronary heart disease) }\end{array}$ & $4(12.5 \%)$ & $15(11.4 \%)$ & 0.857 & $8(30.8 \%)$ & $11(8.0 \%)$ & 0.001 \\
\hline Stroke & $4(12.5 \%)$ & $16(12.1 \%)$ & 0.953 & $4(15.4 \%)$ & $16(11.6 \%)$ & 0.588 \\
\hline Smoking & $1(3.1 \%)$ & $16(12.1 \%)$ & 0.134 & $1(3.8 \%)$ & $16(11.6 \%)$ & 0.234 \\
\hline Obesity $\left(\mathrm{BMI}>30 \mathrm{~kg} / \mathrm{m}^{2}\right)$ & $1(3.1 \%)$ & $25(18.9 \%)$ & 0.028 & 5 (19.2\%) & $21(15.2 \%)$ & 0.607 \\
\hline
\end{tabular}

Abbreviations: $\mathrm{BMI}=$ body mass index; $\mathrm{Cl}=$ cardiac index; $\mathrm{CO}=$ cardiac output

(b)

\begin{tabular}{|c|c|c|c|c|c|c|}
\hline & $\begin{array}{l}\text { Elevated SVRI } \\
\quad(n=72)\end{array}$ & $\begin{array}{l}\text { Normal or low } \\
\text { SVRI ( } n=92)\end{array}$ & $P$ value & $\begin{array}{l}\text { Elevated SVR } \\
\quad(n=108)\end{array}$ & $\begin{array}{l}\text { Normal or low } \\
\text { SVR }(n=56)\end{array}$ & $P$ value \\
\hline Gender & & & 0.015 & & & 0.76 \\
\hline Male & 37 (51.4\%) & 30 (32.6\%) & & 45 (41.7\%) & 22 (39.3\%) & \\
\hline Female & 35 (48.6\%) & $62(67.4 \%)$ & & 63 (58.3\%) & $34(60.7 \%)$ & \\
\hline Age (years) & $64.9 \pm 13.5$ & $72.1 \pm 14.9$ & 0.002 & $67.8 \pm 14.4$ & $71.3 \pm 15.2$ & 0.147 \\
\hline Weight (kg) & $65.7 \pm 11.8$ & $58.6 \pm 12.0$ & $<0.001$ & $61.8 \pm 12.0$ & $61.4 \pm 13.2$ & 0.821 \\
\hline Height (cm) & $157.3 \pm 8.9$ & $154.7 \pm 10.2$ & 0.081 & $155.3 \pm 9.1$ & $156.9 \pm 10.8$ & 0.325 \\
\hline BMI $\left(\mathrm{kg} / \mathrm{m}^{2}\right)$ & $26.5 \pm 4.4$ & $24.4 \pm 3.9$ & 0.001 & $25.6 \pm 4.3$ & $24.8 \pm 4.2$ & 0.287 \\
\hline Diabetes & 17 (23.6\%) & 23 (25.0\%) & 0.837 & 25 (23.1\%) & 15 (26.8\%) & 0.607 \\
\hline Hyperlipidaemia & $17(23.6 \%)$ & $36(39.1 \%)$ & 0.035 & $30(27.8 \%)$ & $23(41.1 \%)$ & 0.084 \\
\hline $\begin{array}{l}\text { Heart disease (congestive heart failure or } \\
\text { coronary heart disease) }\end{array}$ & $8(11.1 \%)$ & $11(12.0 \%)$ & 0.867 & 10 (9.3\%) & $9(16.1 \%)$ & 0.196 \\
\hline Stroke & $9(12.5 \%)$ & $11(12.0 \%)$ & 0.916 & $12(11.1 \%)$ & $8(14.3 \%)$ & 0.556 \\
\hline Smoking & $10(13.9 \%)$ & $7(7.6 \%)$ & 0.190 & $11(10.2 \%)$ & $6(14.3 \%)$ & 0.916 \\
\hline Obesity (BMI >30 kg/m²) & $15(20.8 \%)$ & $11(12.0 \%)$ & 0.122 & $17(15.7 \%)$ & $9(16.1 \%)$ & 0.956 \\
\hline
\end{tabular}

Abbreviations: $\mathrm{BMI}=$ body mass index; SVR = systemic vascular resistance; $\mathrm{SVRI}=$ systemic vascular resistance index

TABLE 4. Nature of the incidents in which antihypertensive drugs prescribed did not correlate with the patient's haemodynamic abnormality $(n=25)$

\begin{tabular}{lc}
\hline Incidents & No. (\%) of patients \\
\hline (1) Elevated SVR or SVRI, yet given antihypertensives other than ACEI, ARB, and/or CCB & 11 (44) \\
(2) Reduced SVR or SVRI, yet given ACEI, ARB, and/or CCB & 0 \\
(3) Elevated CO or Cl, yet given antihypertensives other than beta blocker or diuretic & $5(20)$ \\
(4) Reduced CO or Cl, yet given beta blocker and/or diuretic & $7(28)$ \\
Combination of (1) and (4) & $1(4)$ \\
Combination of (2) and (3) & $1(4)$
\end{tabular}

Abbreviations: $\mathrm{ACEI}=$ angiotensin-converting enzyme inhibitors; $\mathrm{ARB}=$ angiotensin II receptor blockers; $\mathrm{CCB}=$ calcium channel blockers; $\mathrm{Cl}$ = cardiac index; $\mathrm{CO}$ = cardiac output; $\mathrm{SVR}$ = systemic vascular resistance; $\mathrm{SVRI}$ = systemic vascular resistance index 
included a beta blocker as a first-line drug. ${ }^{15,16}$ In contrast, both the current European and Canadian hypertension guidelines retain diuretics and beta blockers as first-line options, and the results from our study appear to support this. ${ }^{20,21}$

In this study setting, patients with elevated CI were more likely to be older, female, and have lower body weight, height and BMI, while those with predominantly elevated SVRI were more likely to be younger, male, and have higher body weight and BMI.

For patients included in our study, the initiation of pharmacologic treatment was in keeping with the latest US National Heart, Lung, and Blood Institute recommendations. ${ }^{15}$ Doctors in ED needed to initiate or step up therapy in $43 \%$ of patients in this study. Of these, about $35 \%$ were given an antihypertensive drug that did not correlate with their underlying haemodynamic abnormality. These results suggest that using non-invasive haemodynamic measurements to guide treatment in the ED may optimise the choice of medication for hypertensive patients. Studies have shown that emergency physicians cannot accurately estimate the underlying haemodynamic profile of acutely ill patients..$^{22,23}$ There are several non-invasive haemodynamic measuring devices available on the market. The Nexfin (BMEYE, Amsterdam, The Netherlands) utilising a finger-cuff technology based on the pulse-contour method can also be conveniently applied in the ED setting. ${ }^{22,23}$ As for impedance cardiography, some work has already been done in ED patients with congestive heart failure and non-ED patients with hypertension; nonetheless more work still needs to be done in ED hypertensive patients. ${ }^{17-19,23}$

\section{Limitations}

It is important to acknowledge that to date, there has been little evidence that, in the ED setting, adjusting antihypertensive medications based on haemodynamic parameters can improve long-term BP control or cardiovascular outcome. There are two other limitations to our study. First, as this study was designed for and conducted in the ED setting, patients may often have presented with injury, pain, anxiety, infections, fever, and other factors that could give rise to transiently elevated BP up to $160 / 100$ $\mathrm{mm} \mathrm{Hg}$ or above. White coat hypertension is also a potential source of bias. This is indeed the same kind of clinical scenario that ED doctors in practice need to manage, in which the elevated BP often requires further observation before a decision for drug intervention can be made. In our study protocol, this period of observation ranged from 2 to 14 days, and we excluded patients with severely elevated BP that was not sustained. As a result, 54 (23\%) of the 232 initially recruited patients were excluded. We believe that by obtaining BP measurements on two separate occasions, we have excluded most of the patients affected by factors causing transient hypertension. We did not choose a hypertension out-patient clinic to recruit our subjects because our intention was to obtain results that can be directly relevant for ED doctors. Second, many patients who present to the ED are already on concomitant antihypertensive drugs that can affect their haemodynamic values. Although we were aware of this confounding factor, we did not aim to study the correlation, nor did we subject our study patients to drug washout periods. In our study, 121 (74\%) patients were on concomitant medications that might influence haemodynamic values. Regardless of whether or not patients are already on antihypertensive medications, defining haemodynamic derangement would still be valuable in guiding decision-making for the choice of antihypertensive drug at the point-of-care, be it introducing a first-line drug, adding a different drug for combination therapy, or increasing the dose of an existing drug.

\section{Conclusions}

This study identified the profile of haemodynamic characteristics in Hong Kong ED patients with poorly controlled hypertension. Antihypertensive drugs prescribed in the ED did not correlate with the patient's primary haemodynamic derangement in approximately $35 \%$ of cases. Therefore, a potential exists for optimising treatment by a haemodynamically guided approach to drug selection. A randomised controlled trial is needed to prove if such an approach will indeed result in better BP control, achievement of haemodynamic normalisation, and better outcomes.

\section{References}

1. Kearney PM, Whelton M, Reynolds K, Muntner P, Whelton PK, He J. Global burden of hypertension: analysis of worldwide data. Lancet 2005;365:217-23.

2. Guo F, He D, Zhang W, Walton RG. Trends in prevalence, awareness, management, and control of hypertension among United States adults, 1999 to 2010. J Am Coll Cardiol 2012;60:599-606.

3. Lloyd-Jones D, Adams R, Carnethon M, et al. Heart disease and stroke statistics-2009 update: a report from the American Heart Association Statistics Committee and Stroke Statistics Subcommittee. Circulation 2009;119:e21181.

4. Sarnak MJ, Greene T, Wang X, et al. The effect of a lower target blood pressure on the progression of kidney disease: long term follow-up of the Modification of Diet in Renal Disease Study. Ann Intern Med 2005;142:342-51.

5. Krum H, Jelinek MV, Stewart S, Sindone A, Atherton JJ; National Heart Foundation of Australia; Cardiac Society of Australia and New Zealand. 2011 Update to National Heart Foundation of Australia and Cardiac Society of Australia and New Zealand Guidelines for the prevention, detection 
and management of chronic heart failure in Australia, 2006. Med J Aust 2011;194:405-9.

6. Rashid P, Leonardi-Bee J, Bath P. Blood pressure reduction and secondary prevention of stroke and other vascular events: a systematic review. Stroke 2003;34:2741-8.

7. Victor RG. Systemic hypertension: mechanisms and diagnosis. In: Bonow RO, Mann DL, Zipes DP, et al, editors. Braunwald's heart disease: a textbook of cardiovascular medicine. 9th ed. Philadelphia, US: Elsevier; 2011: 93554.

8. Meyer S, Todd D, Wright I, Gortner L, Reynolds G. Review article: Non-invasive assessment of cardiac output with portable continuous-wave Doppler ultrasound. Emerg Med Australas 2008;20:201-8.

9. Chong SW, Peyton PJ. A meta-analysis of the accuracy and precision of the ultrasonic cardiac output monitor (USCOM). Anaesthesia 2012;67:1266-71.

10. Niska RW. Blood pressure measurements at emergency department visits by adults: United States, 2007-2008. NCHS Data Brief 2011;72:1-8.

11. The National Heart, Lung, and Blood Institute. National Institutes of Health. The Seventh Report of the Joint National Committee on prevention, detection, evaluation, and treatment of high blood pressure. Available from: http://www.nhlbi.nih.gov/guidelines/hypertension/ jnc7full.pdf. Accessed 11 Mar 2015.

12. Browner WS, Newman TB, Cummings SR, et al. Estimating sample size and power: the nitty gritty. In: Hulley SB, Cummings SR, Browner WS, et al, editors. Designing clinical research. 2nd ed. Philadelphia, US: Lippincott Williams \& Wilkins; 2001: 65-91.

13. Smith BE. The USCOM in clinical practice. Sydney: USCOM; 2007.

14. Goetzel RZ, Long SR, Ozminkowski RJ, Hawkins K, Wang S, Lynch W. Health, absence, disability, and presenteeism cost estimates of certain physical and mental health conditions affecting U.S. employers. J Occup Environ Med 2004;46:398-412.

15. James PA, Oparil S, Carter BL, et al. 2014 Evidence-based guideline for the management of high blood pressure in adults: report from the panel members appointed to the Eighth Joint National Committee (JNC 8). JAMA 2014;311:507-20.

16. Krause $\mathrm{T}$, Lovibond $\mathrm{K}$, Caulfield $\mathrm{M}$, McCormack $\mathrm{T}$, Williams B; Guideline Development Group. Management of hypertension: summary of NICE guidance. BMJ 2011;343:d4891.

17. Flack JM. Noninvasive hemodynamic measurements: an important advance in individualizing drug therapies for hypertensive patients. Hypertension 2006;47:646-7.

18. Smith RD, Levy P, Ferrario CM; Consideration of Noninvasive Hemodynamic Monitoring to Target Reduction of Blood Pressure Levels Study Group. Value of noninvasive hemodynamics to achieve blood pressure control in hypertensive subjects. Hypertension 2006; $47: 771-7$

19. Taler SJ, Textor SC, Augustine JE. Resistant hypertension: comparing hemodynamic management to specialist care. Hypertension 2002;39:982-8.

20. Mancia G, Fagard R, Narkiewicz K, et al. 2013 ESH/ESC Guidelines for the management of arterial hypertension: the Task Force for the management of arterial hypertension of the European Society of Hypertension (ESH) and of the European Society of Cardiology (ESC). J Hypertens 2013;31:1281-357.

21. Dasgupta K, Quinn RR, Zarnke KB, et al. The 2014 Canadian Hypertension Education Program recommendations for blood pressure measurement, diagnosis, assessment of risk, prevention, and treatment of hypertension. Can J Cardiol 2014;30:485-501.

22. Nowak RM, Sen A, Garcia AJ, et al. The inability of emergency physicians to adequately clinically estimate the underlying hemodynamic profiles of acutely ill patients. Am J Emerg Med 2012;30:954-60.

23. Neath SX, Lazio L, Guss DA. Utility of impedance cardiography to improve physician estimation of hemodynamic parameters in the emergency department. Congest Heart Fail 2005;11:17-20. 